\title{
足裏加熱が温熱快適性に及ぼす影響とその至適加熱条件に関する検討 THE INFLUENCE OF HEATING THE SOLES OF THE FEET ON THERMAL COMFORT
AND OPTIMUM HEATING CONDITION
}

\author{
寺野真明*, 佐藤康仁**, 久野 覚*** \\ Masaaki TERANO, Yasuhito SATOU and Satoru KUNO
}

\begin{abstract}
It is very popular in East Asia and Japan to heat some parts of the body using a small heating source in slightly cool or cool conditions. The objective of this paper is to clarify the thermal effect of heating the soles of the feet on human thermal comfort and to consider the optimum heating conditions in such cases. Thirteen (13) men participated in these experiments and were exposed to various sole heating conditions. The following results were obtained:

Overall thermal sensation and thermal comfort were not influenced by heating the soles alone. Therefore it was thought that the optimum conditions of a hot panel should be decided by the local thermal sensation on the soles. There was a close correlation between the thermal sensation of the soles and the energy input through the soles' surface and this was used to decide the optimum condition of the hot panel.
\end{abstract}

Keywords : Thermal comfort, Thermal sensation, heat flow, Heating system, Sole, Optimum condition 温熱快適性, 温冷感, 熱流, 暖房, 足裏, 最適条件

1.はじめに

昨今のエネルギー・環境問題への地球的規模での意識の高まりに 伴い，住宅に扔ける高気密高断熱化が強く推奖されつつあるが，一 方では依然として，人体の一部を加熱あるいは冷却する“採暖／採 冷”が日常生活の様々な場面において積極的に活用されている。今 後,この両者をバランスよく用いることで，より大きな快適性の享 受と省エネルギー効果が期待できる。

このためには採暖/採冷がもたらす熱的不均一性の生理心理的影響 を十分に把握することが必要となるが，既存の温熱指標の多くは

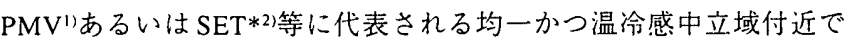
の適用を前提とし，欧米と比較すると断熱気密性に劣り，採暖／採 冷を多用する習慣を有するわが国の温熱環境の評価には適さない。

しかしながら近年，不均一な熟環境が人体に及ほす影響に関する 報告は徐々に増加傾向にある。蔵澄, 堀越ら 3 は作用温度一定条件 での左右不均一な放射場について，堀，伊藤らは嫲暖房による不 均一熱環境について, 熱的快適性への影響とその評価方法をそれぞ れ提案している。また，最近では炬燵採暖について人体への影響と その評価法に関する報告もあり5), 6), 関心の高まりを反映している。 本報告では，放射による寄与が小さい比較的小面積の発熱体によ る採暖形態（電気カーペット等）に着目し，特に椅座時に利用者の
足裏のみが加熱されるケースについて, 温熱快適性への影響と至適 と考えられる加熱条件に関する検討を試みた。この様な採暖形態は 身近なものであるにも関わらず，十分その効果が検討され，最適化 が図られているとは言えない現状にある。

\section{2. 実験計画}

2.1. 実験設備

人工気象室 $(\mathrm{D} 3.0 \mathrm{~m} \times \mathrm{W} 3.0 \mathrm{~m} \times \mathrm{H} 2.35 \mathrm{~m})$ 内に，図1に示す二種 の足裏加熱装置を設置し, 二種類の実験（実験 1 及び 2）を実施し た。実験 1 では室内に構成された疑似床に箱部を掘り下げ，その底 面に面状発熱体（以後パネルとする）を設置し，疑似床面に腰掛け た被験者の足哀を様々な条件で加熱した。パネルは電気コードヒー ター, 合板，アルミシートより構成し，その上にカーペット等の各 種表装材を張り付け，用いた。パネル表面温度（以後パネル温度と する）を K 型熱電対を用い検出し，ON-OFF 制御により所定温度に 維持した。

実験 1 設備では，箱構造ゆえに箱部空気温度が上昇し易いなどの 特異な性状が認められたため, 電気式あるいは温水循環型パネルを 実験室床に直接設置し，実験 2 を実施した。実験 1 及び 2 におりる 各パネル面積は各 $1111 \times 790 \mathrm{~mm}, 1635 \times 755 \mathrm{~mm}$ であった。
* 松下電工二(侏)解析技術研究所

** 松下電工侏)解析技術研究所

*** 名古屋大学大学院工学研究科建築学尃攻 教授. 工博
Analytical Technology Research Laboratory, Matsushita Electric Works, Ltd. Analytical Technology Research Laboratory, Matsushita Electric Works, Ltd. Prof., Dept. of Architecture, Faculty of Engineering, Nagoya University, Dr. Eng. 


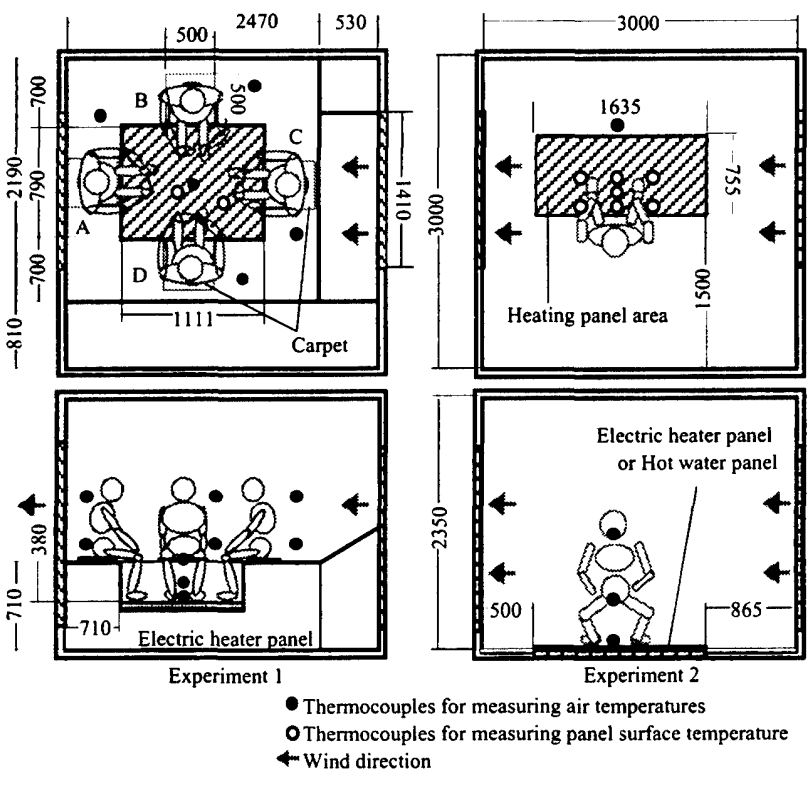

図 1。実験設備

\section{2. 設定条件}

室温 16，18，20年，相対湿度 40\%RH 基準環境として設定した。 均一な環境構成のため換気回数が50回／時と大きいが, 大面積の吹 き出し/吸い込み口を用い, 人体近傍での気流速度が $0.15 \mathrm{~m} / \mathrm{s}$ を越 えないよう注意した。

パネル表装材として 4 種, 塩化ビニールシート，カーペット，木 質フローリング材, 夕夕ミを用意し, 各表装材での表面温度は23か

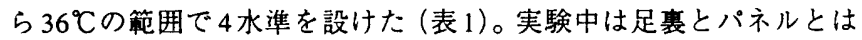
可能な限り安定した接触を保つ様, 各被験者に指示した。

\section{表 1. 実験条件}

\begin{tabular}{|c|c|c|c|c|c|c|c|c|c|c|c|}
\hline $\begin{array}{l}\text { Exp. } \\
\text { No. }\end{array}$ & Cond. No. & $\begin{array}{l}\text { Surface } \\
\text { material }\end{array}$ & {$\left[\begin{array}{c}\text { Air temp. } \\
(\operatorname{deg} \mathrm{C})\end{array}\right]$} & $\begin{array}{c}\text { Pancl } \\
\text { temp. } \\
\text { (deg C) }\end{array}$ & Remark & $\begin{array}{l}\text { Exp. } \\
\text { No. }\end{array}$ & Cond. No. & $\begin{array}{l}\text { Surface } \\
\text { material }\end{array}$ & $\begin{array}{l}\text { Air temp. } \\
\text { (deg C) }\end{array}$ & $\begin{array}{l}\text { Panel } \\
\text { temp. } \\
\text { (deg C) }\end{array}$ & Remark \\
\hline 1 & W]623 & Wood & 16 & 23 & & 2 & T1826_E & Talami & 18 & 26 & \\
\hline 1 & W1627 & Wood & 16 & 27 & & 2 & T1831_E & Tatami & 18 & 31 & \\
\hline 1 & W163! & Wood & 16 & 31 & & 2 & $\mathrm{~T} 1836 \mathrm{E}$ & Tatani & 18 & 36 & \\
\hline 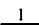 & W1635 & Wood & 16 & 35 & & 2 & CO1800_E & Vind & 18 & & \\
\hline 1 & W1823 & Wood & 18 & 23 & & 2 & CO1826_E & Vind & 18 & 26 & \\
\hline 1 & W1827 & Wood & 18 & 27 & & 2 & CO1831_E & $V_{\text {niny }}$ & 18 & 31 & \\
\hline 1 & w1831 & Wood & 18 & 31 & Subjects age & 2 & CO1836E & $V_{\text {inyl }}$ & 18 & 36 & \\
\hline 1 & w1835 & Wood & 18 & 35 & (SA):Young & 2 & W1800_W & Wood & 18 & & HT:Hot water \\
\hline 1 & W2023 & Wood & 20 & 23 & Humidity $(\mathrm{H})$ & 2 & W1826_W & Wood & 18 & 26 & \\
\hline 1 & W2027 & Wood & 20 & 27 & $: 40 \% \mathrm{RH}$ & 2 & W1831_W & Wood & 18 & 31 & \\
\hline$i$ & $w_{2031}$ & Wood & 20 & 31 & Exposure & 2 & W1836 W & Wood & 18 & 36 & \\
\hline 1 & W2035 & Wood & 20 & 35 & (E): $30 \mathrm{~min}$ & 2 & W1800_ES & Wood & 18 & & HT:Electric \\
\hline 1 & $\mathrm{CH} 1823$ & $\sqrt{\mathrm{m} m i}$ & 18 & 23 & Heater type & 2 & W1826_ES & Wood & 18 & 26 & No-radiation \\
\hline 1 & CH1827 & Vint & 18 & 27 & (HT): Electric & 2 & W183I_ES & Wood & 18 & 31 & \\
\hline 1 & $\mathrm{CH} 1831$ & Vimyl & 18 & 31 & & 2 & W1836 ES & Wood & 18 & 36 & \\
\hline 1 & $\mathrm{CH} 1835$ & $V_{\text {nul }}$ & 18 & 35 & & 2 & W1800_EB & Wood & 18 & & Heating area \\
\hline 1 & CA1831 & Cappet & 18 & 31 & & 2 & W1826_EB & Wood & 18 & 26 & (HA):Botom \\
\hline 1 & CAI838 & Cappet & 18 & 38 & & 2 & W1831_EB & Wood & 18 & 31 & HT:Ekectric \\
\hline 1 & CAI842 & Capper & 18 & 42 & & 2 & W1836 EB & Wood & 18 & 36 & \\
\hline 1 & CA1846 & Carpet & 18 & 46 & & 2 & CAl 800 _EB & Carpet & 18 & & \\
\hline 1 & W1823R & Wood & 18 & 23 & (W1823) & 2 & CAI826_EB & Carpet & 18 & 26 & \\
\hline 1 & W1827H & Wood & 18 & 27 & $\mathrm{H} .60 \%$ RH & 2 & CAI831_EB & Carpet & 18 & 31 & \\
\hline$t$ & W/827L & Wood & 18 & 27 & $\mathrm{E}: 60 \mathrm{~min}$ & 2 & CAI836 EB & Carpet & 18 & 36 & \\
\hline 1 & WI I835R & Wood & 18 & 35 & (W1835) & 2 & T1800_EB & Tatami & 18 & & \\
\hline 1 & W $1823 E$ & Wood & 18 & 23 & SA:Elderty & 2 & T1826 EB & Tatami & 18 & 26 & \\
\hline I & WI83SE & Wood & 18 & 35 & SA:Elderty & 2 & T1831_EB & Tatami & 18 & 31 & \\
\hline$\frac{1}{2}$ & W1800E & Wood & 18 & & HT:Elecroric & 2 & T1836 EB & Tatami & 18 & 36 & \\
\hline$\frac{1}{1}$ & WI 1826 E E & Wood & 18 & 26 & & 2 & CO1800 EB & Vind & 18 & & \\
\hline 2 & W1831_E & Wood & 18 & 31 & & 2 & COI826EB & Vingl & 18 & 26 & \\
\hline 3 & $w 1836 \mathrm{E}$ & Wood & 18 & 36 & & 2 & CO1831_EB & Vinyl & 18 & 31 & \\
\hline 2 & CAI800_E & Carpet & 18 & & & 2 & $\mathrm{CO} 01836 \mathrm{~EB}$ & $v_{\text {ind }}$ & 18 & 36 & \\
\hline 2 & CAl826_E & Cappet & 18 & 26 & & 2 & W1800_WB & Wood & 18 & & HA:Botom \\
\hline 2 & CA183I_E & Cappe! & 18 & 31 & & 2 & W1826_WB & Wood & 18 & 26 & HT:Hot waler \\
\hline 2 & CA1836 E & Canpet & 18 & 36 & & 2 & WI831_WB & Wood & 18 & 31 & \\
\hline 2 & $\mathrm{~T} 1800 \mathrm{E}$ & Tatami & 18 & & & 2 & W1836 WB & Wood & 18 & 36 & \\
\hline
\end{tabular}

本報告では表 1 記載の実験条件の内, まず室温及び表装材一定条 件について, 足亭加熱と温熱快適性との関係について考察を試みる
(図中網掛け部)。また実験中, 被験者位置によっては僅かな気流感 と共に空気温度の不均一性が指摘されたため, 各被験者近傍の上下 空気温度（足元から頭部に至る3〜5点）の実測データに基づき，不 適と考えられるケースを除去した。以上より, 実験中を通じての上 下空気温度 $3 \sim 5$ 点の平均が $18.5 \sim 19.5^{\circ} \mathrm{C}$, 標準偏差が $1.0 \mathrm{deg}$ 以内, 木質表装材使用時となる条件を满たす被験者のみを抽出した。実測 データに基づく環境条件の再設定結果を表 2 に示す。

表 2. 抽出後の実験条件

\begin{tabular}{c|c|c|c|c|c|c|c|c}
\hline Exp. No. & 1 & 1 & 1 & 1 & 2 & 2 & 2 & 2 \\
\hline Air Temp. (deg C) & 18.9 & 19.0 & 19.0 & 19.1 & 18.7 & 19.0 & 19.1 & 19.4 \\
\hline Panel Temp. (deg C) & 26.2 & 29.3 & 36.1 & 38.2 & 19.3 & 25.5 & 30.9 & 34.1 \\
\hline Panel Surface Material & Wood & Wood & Wood & Wood & Wood & Wood & Wood & Wood \\
\hline Subjects' number & 5 & 4 & 5 & 2 & 4 & 4 & 4 & 3 \\
\hline
\end{tabular}

\section{3. 実験手順}

被験者は指定着衣に着替え，実験開始約 15 分前に実験室に入室， 各種センサーを取り付け, 実験に関する説明を受けた後, 実験を開 始した。実験開始後20３0分間は接触前状態を安定させるため, 足 襄を空中に放置するように指示した。

実験 1 では 30 分間の待機後, 30 分間足車をパネルに接触（加熱） し，その後一旦実験室から退室，30分間程度の休息の後，別条件に

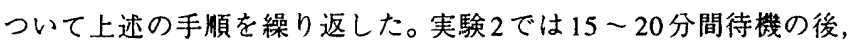
パネル温度を変更し, 足軎を 15 分間加熱するサイクルを 4 回繰り返 した。以上を図 2 に示す。実験中，図中の時間間隔で温熱快適性に 関する主観評価を行うと共に，熱流，皮店温度を10秒毎に計測した。

実験 1 では午後 1 時から, 途中約 30 分間の休䄭を挟み，午後 3 時 30 分に終了し，同時に4名の被験者を計測した。実験 2 は午前及び 午後各 1 名の 1 日 2 回実施した。実験 1 は 1996 年 2 月 1 日から 3 月 15 日, 実験 2 は 1997 年 2 月 28 日から 4 月 1 日にかけて実施した。
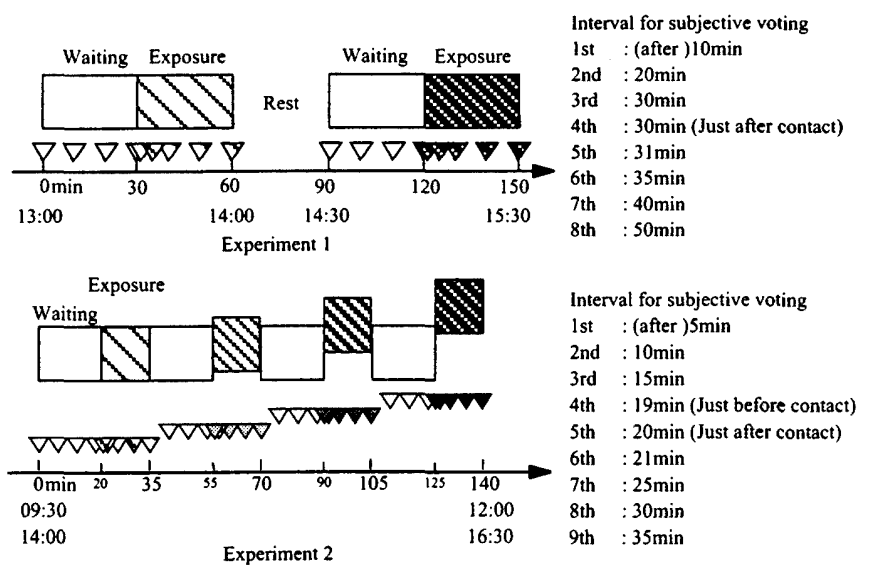

図 2. 実験手順

\section{4. 被験者}

実験 1 では健康な 20 才代の青年男性 6 名と 60 才代男性 4 名, 実 験2では20才代青年男性3名についてデー夕を収集した。被験者の

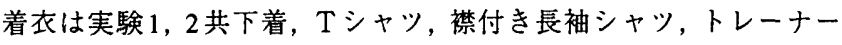
上下および裸足状態とした。花田ら》の単品衣類クロー值と重ね着 クロー值の関係式から推定された着衣量は $0.6 〜 0.7$ cloであった。 実験中，被験者には読書程度の簡単な作業については許可した。 
本報告では青年男性データのみを使用し，60才代男性データにつ いては除外して以降の解析を進める。加齢による影響については次 報以降において検討する予定である。

表 3. 被験者プロフィール

\begin{tabular}{c|c|c|c|c|c}
\hline Exp. No. & Subject's initials & Age (yrs) & Sox & Height (cm) & Wecight (kg) \\
\hline 1 & K.T & 27 & Male & 180 & 78 \\
1 & S.O & 22 & Male & 173 & 65 \\
1 & H.M & 20 & Male & 170 & 56 \\
1 & H.K & 19 & Male & 167 & 60 \\
1 & H.T & 61 & Male & 162 & 62 \\
1 & Y.F & 63 & Male & 172 & 73 \\
1 & H.H & 61 & Male & 165 & 73 \\
1 & T.K & 61 & Male & 165 & 65 \\
1 & K.N & 18 & Male & 170 & 55 \\
1 & H.N & 20 & Male & 186 & 70 \\
\hline 2 & T.N & 20 & Male & 180 & 67 \\
\hline 2 & K.N & 20 & Male & 170 & 55 \\
2 & S.N & 21 & Male & 166 & 63 \\
\hline
\end{tabular}

2.5. 測定項目及び測定方法

\subsection{1. 温熱環境}

各実験条件において，人体近傍空気温度及びパネル温度を 10 秒間 隔で計測した。空気温度計測にはアルミ箔による放射よけを施した 直径 $0.1 \mathrm{~mm}$ の $\mathrm{T}$ 型熱電対を用い，実験 1 ではパネル上 $10 ， 20,40$, $60,110 \mathrm{~cm}$ 付近，実験 2 では $10,60,110 \mathrm{~cm}$ の 3 点にて計測した。 一方パネル温度はアルミあるいは透湿性テープによりパネル表面 に固定されたT型熱電対により計測した。表 4 に各実験における計 測項目を，計測点に関しては図 1 に示した。

表 4. 計測項目

\begin{tabular}{|c|c|c|c|}
\hline Items & Apparatues & Position & Number \\
\hline Air temp. & $\begin{array}{l}\text { Thermocouple } \\
\text { covered by aluminum foil } \\
\text { : type, } d=0.2 \mathrm{~mm}\end{array}$ & $\begin{array}{l}10,20,40 \mathrm{~cm} \text { above centre of hot panel } \\
58,113 \mathrm{~cm} \text { above surface of } \\
\text { hot panel nearby each subjects }\end{array}$ & \\
\hline \multirow[t]{2}{*}{ Panel surface temp. } & $\begin{array}{l}\text { Thermocouple } \\
\text { applied by aliminum tape } \\
\text { :T type, } \mathrm{d}=0.2 \mathrm{~mm}\end{array}$ & Panel surface & $\frac{1}{2}$ \\
\hline & $\begin{array}{l}\text { Thermocouple } \\
\text { applied by skintonepore tape } \\
\text { : T type, } \mathrm{d}=0.2 \mathrm{~mm}\end{array}$ & Panel surface & $T$ \\
\hline Skin surface temp. & heat flow sensor & Left sole & 4 \\
\hline Heat flow into sole & heat flow sensor & Left sole & 4 \\
\hline
\end{tabular}

\begin{tabular}{l|l|l|c} 
Experiment 2 & \multicolumn{1}{c}{ Apparatues } & \multicolumn{1}{c}{ Position } & Number \\
\hline Items & $\begin{array}{l}\text { Thermocouple } \\
\text { covered by aluminum foil } \\
\text { Tir temp. }\end{array}$ & $10,60,110 \mathrm{~cm}$ above panel surface & 3 \\
\hline Panel surface temp. & $\begin{array}{l}\text { Thermocouple } \\
\text { applied by skintonepore tape } \\
: T \text { type, } \mathrm{d}=0.2 \mathrm{~mm}\end{array}$ & Panel surface & 7 \\
\hline Skin surface temp. & heat flow sensor & Left sole (left hip and thigh) & $1(2)$ \\
\cline { 2 - 4 } & Thermistor & $\begin{array}{l}\text { Left sole (thigh and left sole) } \\
\text { Left instep } \\
\text { Left shin (waist) }\end{array}$ & 4 \\
\hline Heat flow into sole & heat flow sensor & Left sole (hip and thigh) & 1 \\
\hline
\end{tabular}

\subsection{2. 人体の生理及ざ心理反応}

人体とパネルが接触する足裏において，移動熱流と皮成温度を熱 流計及び熱電対を用いて計測した。各センサーは図3に示す人体部 位に透湿性テープを用いて固定し、デー夕収集間隔は10秒とした。 一方, 熱的快適性, 全身及び局部の温冷感及び床温／室温に対する 要望などの主観量を，1〜10分間隔で収集した。申告には寒暑感, 涼暖感 7 段階尺度及び快適感 7 段階尺度を，足裏温冷感に関しての み非対称な9段階尺度いを用いた。温冷感の分析には寒暑感尺度を 用いた8)。また快適感申告には不快側のみの片側尺度が一般的に用 いられるが, 今回は不均一な熱的環境がもたらす積極的な快適性の 存在が子想されたため，両側尺度を採用した。床温／室温に対する 要望は,「温度を下げたい〜このままでいい一温度を上げたい」の三 択とした。図4に申告尺度を示す。

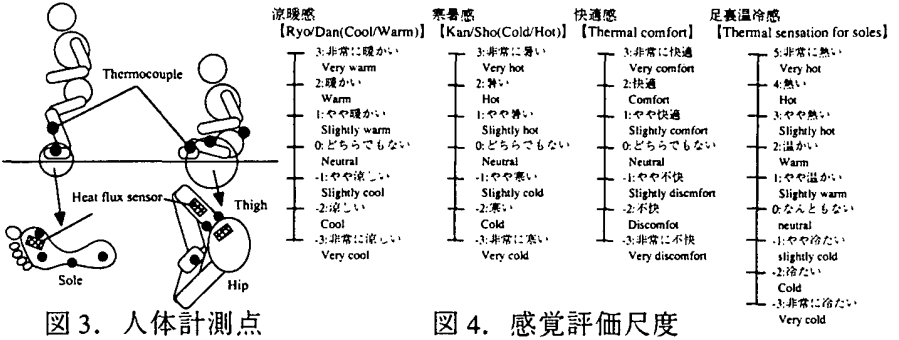

3. 結果

3.1. 環境設定状態

実験 1 及び 2 における被験者近傍空気温度 3 - 5点及びパネル温 度の平均値と標準偏差の時間的変化を図 5 及び 6 に示す。㞬気温度

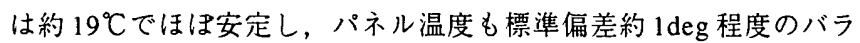
ッキは認められるものの, 足裹接触時には安定に達していることが 確認できる。実験 2 は異なるパネル温度を連続的に提示する実験で あったが，接触時にはおよそ所定の温度に安定していることが確認 できる。

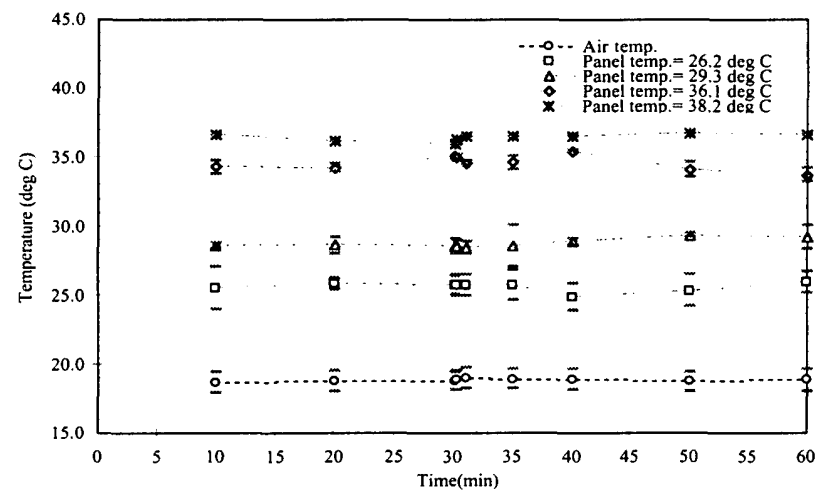

図 5. 実験 1 における空気温度及びパネル温度の時間的変化

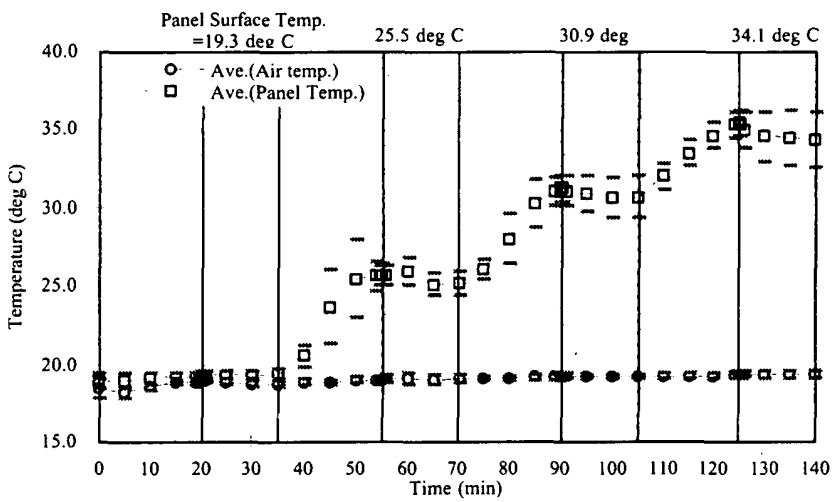

図 6. 実験 2 における空気温度及びパネル温度の時間的変化

\section{2. 足裏加熱が全身の温熱快適性に及ほす影響}

図 7 及び 8 に, 実験 1 における被験者の快適感及び寒暑感申告値 平均の時間的変化の一例を示す。足裏加熱による影響は快適感, 寒 暑感とも不明瞭であり，実験 2 においても同様であった（図 9,10$) 。$ 両実験共, 特に快適感申告值におけるバラッキが大きく, 寒暑感で は比較的バラッキが小さい。これは室温が $19^{\circ} \mathrm{C}$ と温熱中立域に比較 的近く，室温及び足裹加熱がもたらす快適性に関する各人の感じ方 に差があるためと考えられるが，いずれにせよ足赛に限定された加 
熱が全身的な温熱快適性に及ぽす影響は非常に小さいといえる。

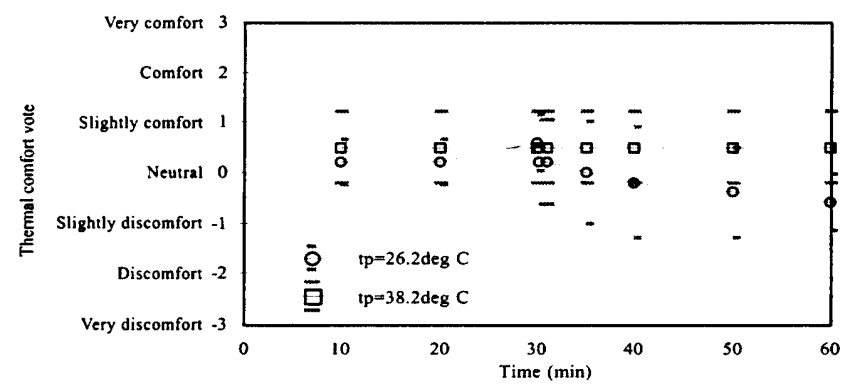

図 7. 快適感申告平均及び標準偏差の変化の例（実験 1）

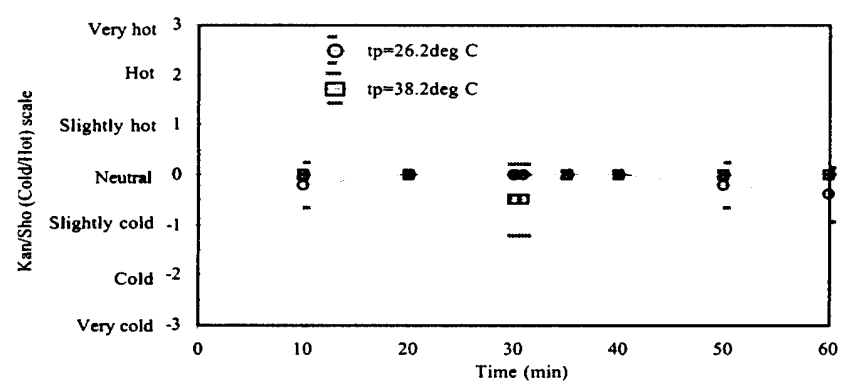

図 8. 寒暑感申告平均及び標準偏差の変化の例（実験 1)

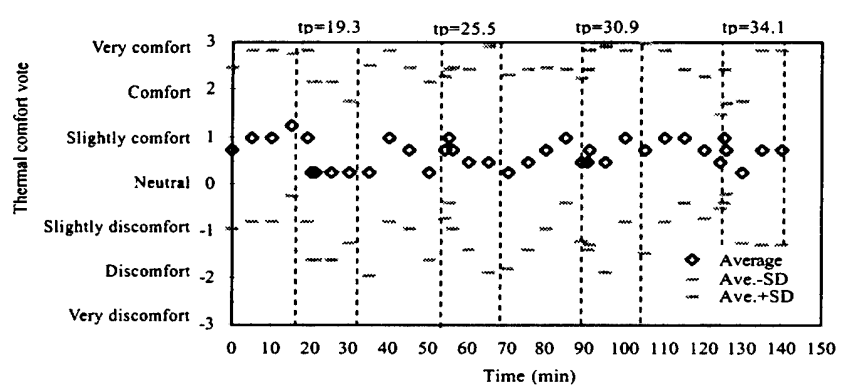

図 9. 快適感申告平均及び標準偏差の変化（実験 2）

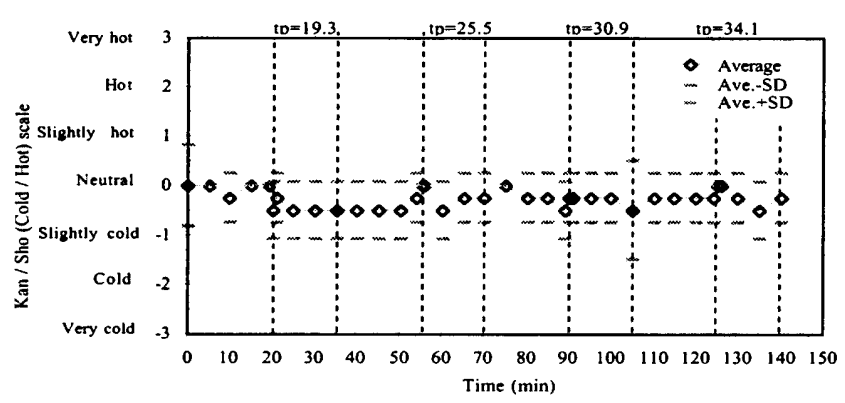

図 10. 寒蒝感申告の平均及び標準偏差の変化（実験 2）

しかしながら，足蓑だけが加熱される暖房形態は古くから存在し， 我々は経験的にその有効性を知っている。こうした暖房形態は本来, 人体の一部に対する不快の解消を目的とするものである。このため 採暖における効果の定量化, 至適条件の検討に際しては, 発熱体と の接触部における快適性あるいは不快性に関する情報が必要となる と同時に，「満足一不満」あるいは「許容できるーできない」等を尺 度とする評価が不可欠であると思われる。

3.3. 接触部における温熟感覚 (足妻温冷感とパネル温度との関係) 以上より小面積パネルー椅座姿势, すなわち足裹だけが加熱され
る場合には，人体と発熱体との接触部の感賞がパネル条件決定上， 最も重要な要因となると考えられる。図 11 は実験 1 において，提示 されたパネル条件に対する足亭温冷感申告の全被験者の平均值の時 間的変化を示したものである。パネル温度 $36.1^{\circ} \mathrm{C}$ の際の待機中の足 衰温冷感が他条件と異なる等不明な点は存在するが, 寒署感, 涼暖 感に比べ,与えられた熱刺激が明確に知覚されていることがわかる。 実験 2 でも同様の結果が得られた。ここで実験 1 及び 2 それ゙れに ついて, パネル温度と足裹温冷感の関係を全データについてプロッ トした（図 12，13）。一次式による回慢では 0.55 から 0.76 程度の決 定係数が得られ，全身的な温熱快適性を示す快適感，寒暑感に比べ， 足亳温冷感とパネル条件との関係は明確であると共に, 加熟条件決 定の判断基準として有効であることがわかる。

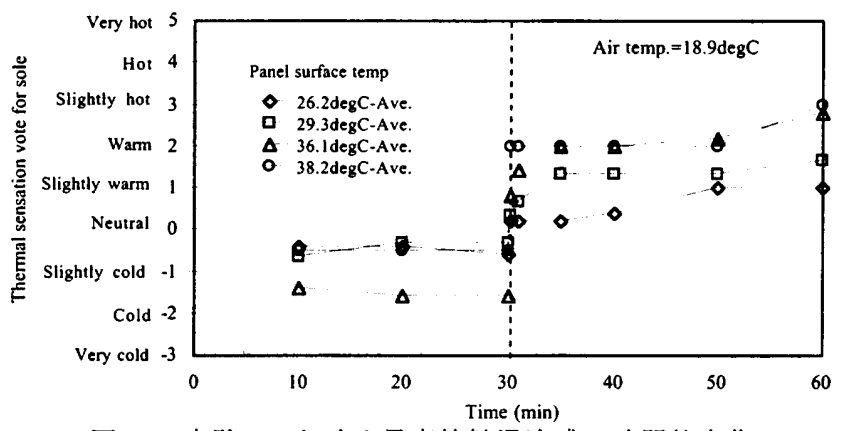

図 11．実験 1 における足裏接触温冷感の時間的変化

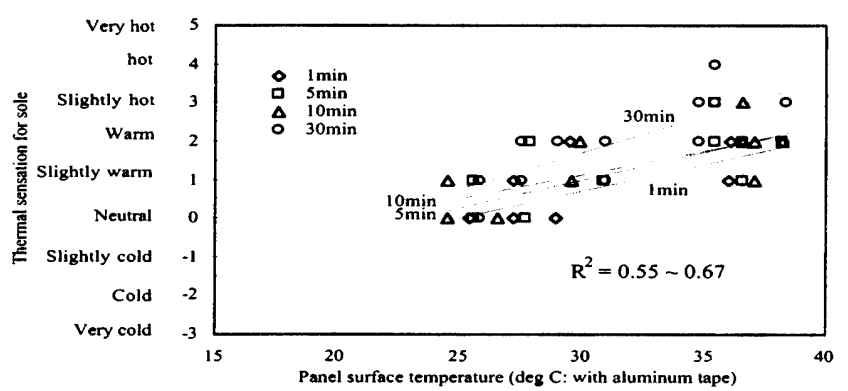

図 12. 実験 1 におけるパネル温度と足衰接触温冷感との関俰

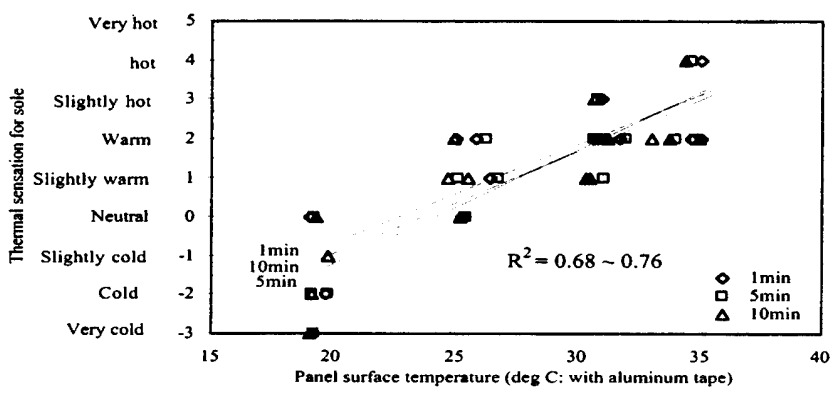

図 13、実験 2 に㧍けるパネル温度と足車接触温冷感との関係

ここで図 12 及び 13 よ実験 1 及び2 でパネル温度一足表温冷感 関係に大きな違いがあることがわかる。以下この相違点について検 討する。図 14 に接触開始 10 分経過時点でのパネル温度一足裹温冷 感関係における実験 1 及び 2 の比較結果を示した。両者に認められ る差異がパネル温度低温域のデータの存在によるものと考え，実験 2 のパネル温度 $19^{\circ}$ C付近のデータを除いた結果が図 15 である。僅か に実験 2 が温かい側に位戛する傾向が認められた。この原因として

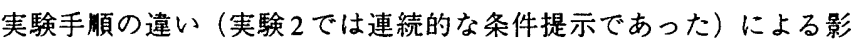


響も考えられたが, 筆者らの体感では20分間の待機は初期状態への 回復には十分と感じられ，両者の差は，パネル構造，材質などのパ ネル全体としての特性の違いによるものではないかと思われる。以 上より, パネル温度一接触温冷感関係に基づく, パネルの至適条件 決定は普遍性に欠ける可能性があり，以下考察ではより普遍性の高 い指標に関する検討を試みる。

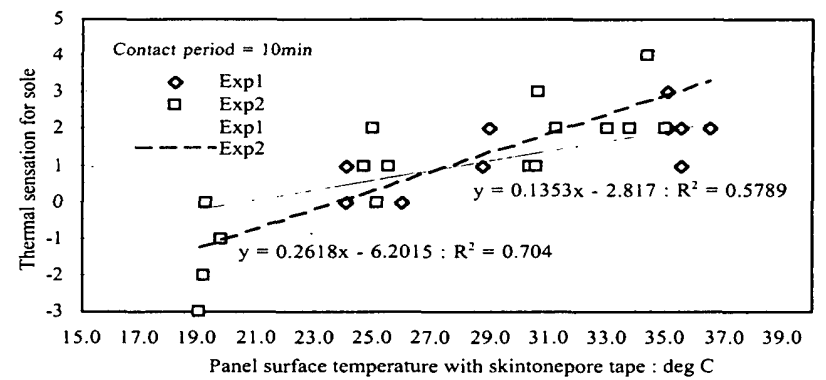

図 14. 実験 1 及び 2 におけるパネル温度一接触温冷感関係

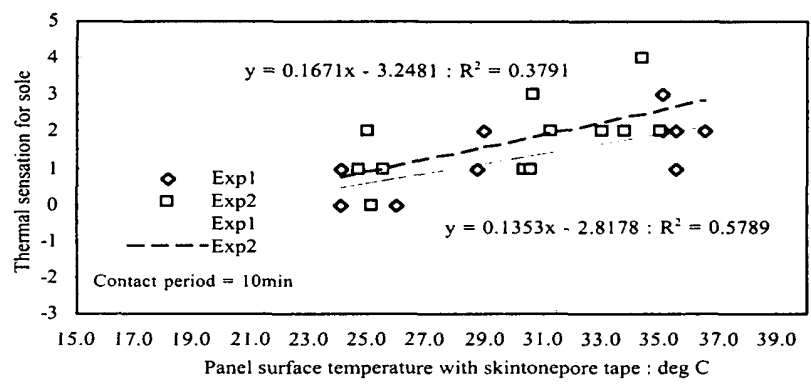

図 15. 低温領域除去後の実験 1 及び 2 の比較

\section{4. 考察}

4.1. 人体への熱的影響と足裏温冷感との関係

前述の様に,パネル温度が同じであっても異なるパネル間では足 裏温冷感は必ずしも一致するとは限らない。これは各パネル固有の 特性が大きく関与するためと考えられるが，松井9).10等はこの問題 に対し人体への直接的な刺激と接触温冷感との関連付けを試み,パ ラメータとして接触直後から人体に流入出した総熱量あるいは, 接 触部皮膚温度の変化量を用いた。図 16 に接触部温度変化, 人体流 入出熱量の定義を示す。
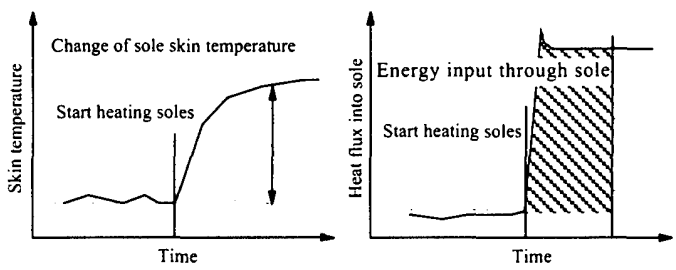

図 16. 接触温冷感定量化パラメータの定義

図 17 は実験 1 及び 2 の人体流入出熱量一接触温冷感関係を 10 分 経過時点において比較した結果である。パネル温度低温域デー夕は 除外した。接触中を通じて両者は良好な一致を示し, 人体流入出熱 量一接触温冷感関係がパネル特性に左右されないことがわかる。

以上より人体流入出熱量を用い，両実験のデータの統合を試みた。 1 分後から 30 分後に至る結果を図 18 に示す。10 分後以降での差異 は明確とは言えないが, 本報告では区別した。一次式による回帰に
比べ,対数近似による回㷌結果の決定係数が僅かであるが高かった。 この際人体流入出熱量値が負となる場合が生じたため, 実際の人体. 流入出熱量値に定数 $(+10)$ を加算した修正値を用い, 近似式を得た。

接触部温度变化による結果を図19に示す。対数近似適用のため接 触部温度変化に $3 \mathrm{deg}$ 加算した修正值を用い, 足裏温冷感との関係を 得た。人体流入出熱量同様，実験間の差は消失するが，決定係数は やや小さい值が得られた。

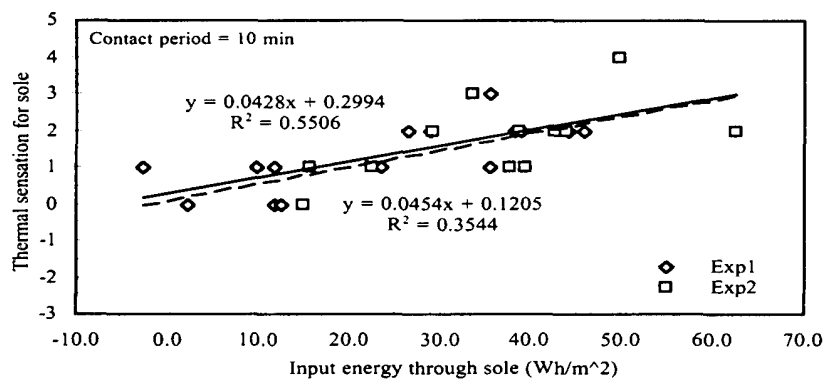

図 17.人体流入出熱量による実験 1 及び 2 の比較

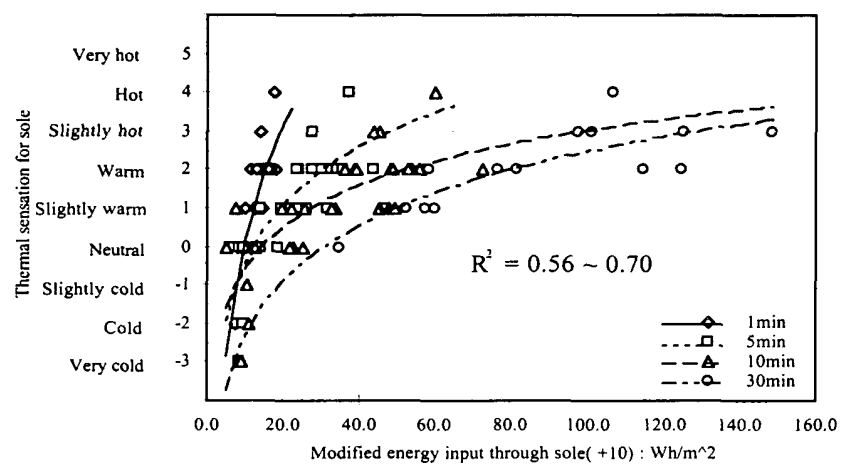

図 18. 接触温冷感と人体流入出熱量との関係 (室温 $19^{\circ} \mathrm{C}$ )

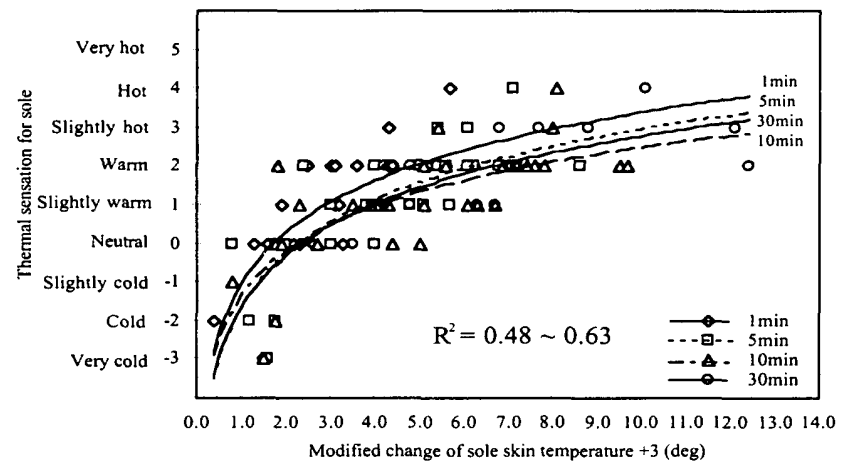

図 19. 接触温冷感と接触部温度変化との関係 (室温 $19^{\circ} \mathrm{C}$ )

\section{2. 既往研究結果との比較}

得られた人体流入出熱量と接触温冷感との関係について, 松井ら 11).12)の結果との比較を試みた（図20）。接触直後における差異は, 熱 量值算出方法における違いが影響している可能性が高いが, こうし た影響が小さい10～30分後は，筆者らの結果が松井らに対しやや 右方向にシフトし，足裏温冷感中立時にも熱供給が必要であること を示している。今回比較に用いた松井らのデータが立位姿勢である こと, 温熱中立域に近い室温 $21^{\circ} \mathrm{C}$ 付近での計測結果であることなど が本報告における結果との間に差違が生じた原因と考えられる。 


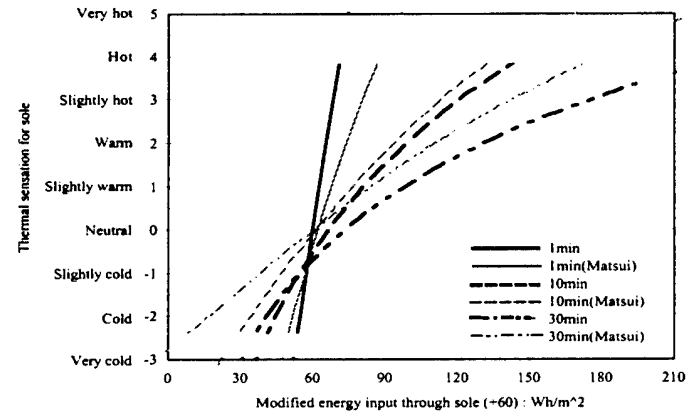

図 20. 既往研究結果との比較 (人体流入出熱量一足裹温冷感関係)

\section{3. 至適パネル条件に関する検討}

図 21 にパネル温度に対して「0：ちょうどいい」との申告が得ら れるデータについて, 全データ数に対する各足裹温冷感申告値の申 告数の割合を示した。0〜30分の接触時間を通じて「2:温かい」で パネルに対する满足度が高い様子が伺える。

ここで小面積パネルによる足妻加熱時の至適条件を，“パネル温度 変更の必要性を感じない状態”と考えると，各接触時間で接触温冷 感申告が「2：温かい」となる人体流入出熱量值が得られることが 必要となる。これらの值は図 18 より算出可能である。

以上より例として実験 1 使用パネルにおける人体流入出熱量一床 温関係（図 22）から，接触温冷感申告値 2 が得られるパネル温度を 得た。実験 2 における推定結果と共に表 5 にまとめる。今後データ 数の拡充を図る必要があるが, 接触から10分間程度は比較的高温が 求められ，30分も経過すると求められるパネル温度は低下する傾向 が示されている。また，実験 1 及び2の各パネルでは同等の温冷感 が得られるパネル温度が異なることがわかる。

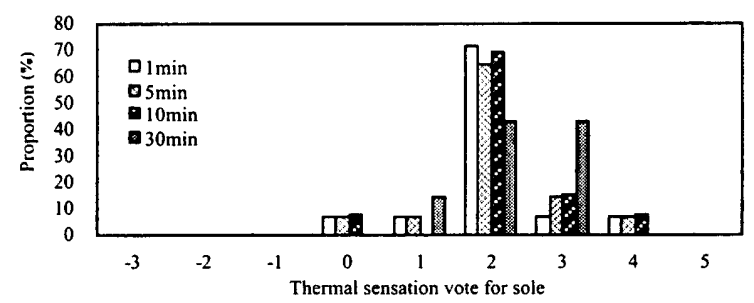

図 21.パネル温度に満足する際の接触温冷感申告の割合

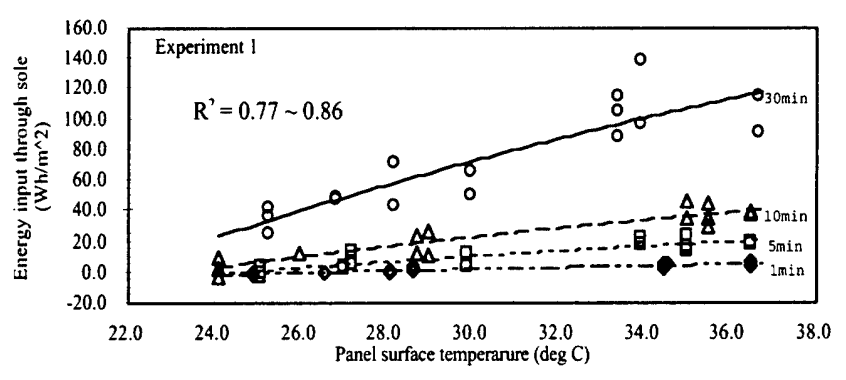

図 22. 実験 1 使用パネルの表面温度と人体流入出熱量との関係

表 5. パネル至適条件と各実験における最適パネル温度

\begin{tabular}{c|c|c|c|c}
\hline Contact period & & Optimum cond. & \multicolumn{2}{|c}{ Optimum panel temps. (deg $\mathrm{C})$} \\
\cline { 4 - 5 }$(\min )$ & Equation & $\left(\mathrm{Wh} / \mathrm{m}^{\wedge} 2\right)$ & Expl & Exp2 \\
\hline $1 \min$ & $\mathrm{y}=4.41 \operatorname{Ln}(\mathrm{x}+10)-10.06$ & 5.4 & 36.8 & 30.8 \\
$5 \min$ & $\mathrm{y}=2.20 \operatorname{Ln}(x+10)-5.49$ & 20.2 & 36.4 & 30.4 \\
$10 \mathrm{~min}$ & $\mathrm{y}=1.56 \operatorname{Ln}(\mathrm{x}+10)-4.14$ & 41.5 & 37.2 & 31.6 \\
$30 \mathrm{~min}$ & $\mathrm{y}=2.09 \operatorname{Ln}(\mathrm{x}+10)-7.14$ & 69.2 & 29.6 & \\
\hline
\end{tabular}

\section{5.まとめ}

本報では，個人対応，椅座姿势での利用を主目的とする小面積面 状発熱体を想定し, 足衰だけが加熱される場合の温熱快適性に関し て体感評価実験を実施し，以下の知見を得た。

1）足亭のみの加熱では全身的温熱快適性に影響する程の効果は得 られず，主に局部不快感（冷たさ，寒さ）の解消が主となる。この 時, 加熱により発生する局所の感覚すなわち足衰温冷感がパネルに よりもたらされる快適性を決定する主要因となるものと考えられる。 2) 足衰温冷感はパネル温度との関連性が高いが, 両者の関係は各 パネルに依存し，普遍性に欠ける可能性が高い。本報告では人体へ の直接的な熱的刺激を表現した人体流入出熱量及び接触部の温度変 化がパネルの諸特性に左右されることなく，足裹温冷感との間に高 い相関性を有することを確認し，木質床に関する定量式を得た。

3）接触温冷感レベル 2 (温かい) の時, パネルに対する満足度は 最も高い。このことから各接触時間毎の至適状態を得るための人体 流入出熱量值を得, 試みに至適に感じるパネル温度を実験で用いた パネルについて求めた。

本報告では木質表装材に限定し，解析を進めた。このため他の素 材に関する確認を進めると共に, 室温等のその他要因の影響につい ても検討する必要がある。また, 人体流入出熱量の計測, 推定方法 についても検討を進めており，引き続き報告を予定している。

\section{参考文畝}

1) Fanger, P. O :Thermal Comfort 2ed ed, Facsimile of 1970ed., McGrow- Hill, New York, 1972

2) Gagge, A.P : Fobelets, A.P., Berglund, L.G : A Standard Predictive Index of Human Response to the Thermal Environment, ASHRAE Transactions, Vol.92, Part28, pp709-731

3) 藏澄美仁, 堀越哲美, 平山慶太郎, 土川忠浩, 小林陽太郎：非対称及び不 均一な等放射環境の人体影繁に閶する研究，日本建築学 会計画系詥文報告 集，第 447 号，17-26，1993

4) 堀咗治, 伊藤直明, 須永修通, 室恵子: 不均一熟環境における熟的快適性 の評価に関する研究，日本建築学会計画系論文集，第 501 号，37-44，1997 5) 渡透慎一, 堀越哲美, 三好結城, 宮本征一, 水谷章夫 : 炬琏採暖が人体に

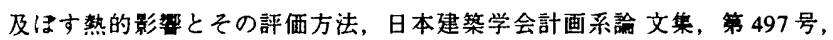
39-45, 1997

6) 渡息慎一，堀越哲美，三好結城，宮本征一：炬燅使用時における人体の熟 的快適性の検討とその温熟刘果の定量化，日本建築学会計画系論文集，第 497 号, 47-52, 1997

7)花田嘉代子, 三平和雄, 佐藤由美: 倵維製品消费科学会誌, $22,430,1981$ 8) 久野觉: 非定常時における温熟生理・心理反応, 日本建築学会第 23 回熟シ ンポジウム, pp.69 76, 1973

9) 松井勇, 笠井芳夫：仕上材の感触に関す万研究 - その 1 温冷感触, 日本建 築学会論文報告集，第 263 号, pp. $21 ３ 1$, 昭 53.1

10) 松井勇, 笠井芳夫：仕上材の感触に関する研究一温冷感触その 2 , 日本建 築学会論文報告集，第 264 号，1-12，昭 55.8

11)松井勇, 沖倉传代：模擬足による床の接触温熱感の評価方法その 3 , 空気

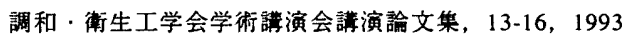

12)松井勇, 湯浅昇, 沖倉渗代: 床の接触温熱感に関する研究その 2 , 日本建 築学会大会学術講演梗概集，641-642,1993

(1998年 7 月 3 日原稿受理, 1999 年 6 月 11 日採用決定) 